\title{
Performance analysis of stand-alone hybrid (wind-photovoltaic) energy system
}

\section{Şebekeden bağımsız hibrit sistemin (rüzgar-fotovoltaik) performans analizi}

\author{
Oktay ARIKAN ${ }^{1}$ (D) Evren ISSEN²* (iD), Bedri KEKEZOĞLU ${ }^{3}$ (D) \\ 1,3Department of Electrical Engineering, Faculty of Electrical-Electronics, Yildiz Technical University Istanbul, Turkey. \\ oarikan@yildiz.edu.tr, bkekez@yildiz.edu.tr \\ 2Department of Electrical-Electronics Engineering, Faculty of Engineering, Kirklareli University, Kirklareli, Turkey. \\ evren.isen@klu.edu.tr
}

Received/Geliş Tarihi: 07.06.2018, Accepted/Kabul Tarihi: 01.11.2018

doi: $10.5505 /$ pajes.2018.98958

* Corresponding author/Yazıșılan Yazar

Research Article/Araștırma Makalesi

\begin{abstract}
Sizing of PV panel, wind turbine and storage batteries in hybrid energy systems is the most important research topic for a system design. There are many studies in the literature, using different approaches about sizing of hybrid renewable energy systems. In this study, experimental and simulation performance differences of the installed hybrid system are presented. The system that is installed in Yildiz Technical University, has $600 \mathrm{~W}$ wind turbine, $2 \times 320 \mathrm{~W}$ photovoltaic (PV) panel group and $4 \times 210$ Ah batteries. A maximum power point tracking (MPPT) controller, a hybrid controller and an inverter are utilized to control the panels, wind turbine and power flow. A weather station is used to measure the weather conditions such as wind speed, temperature, radiation, and electrical quantities are recorded by a data logger. The system is modelled depending on the datasheets of the components, and the modelling results are compared with experimental results.
\end{abstract}

Keywords: Hybrid system, Renewable energy, Wind energy
Öz

Hibrit enerji sistem tasarımında fotovoltaik panel, rüzgar türbini ve akülerin boyutlandırılması en önemli araştırma konusudur. Literatürde hybrid yenilenebilir enerji sistemlerinin boyutlandırlmasında farkl yaklaşımlar kullanan çok sayıda çalışma bulunmaktadır. Bu çalışmada, kurulan bir hibrit sistemin deneysel ve simülasyon sonuçları arasındaki farklllkklar ortaya konmuştur Yıldı Teknik Üniversite'sinde kurulan sistem $600 \mathrm{~W}$ rüzgar türbini, $2 \times 320 \mathrm{~W}$ fotovoltaik panel ve $4 \times 210 \mathrm{Ah}$ akü içermektedir. Maksimum güç noktası takip kontrol cihazı, hibrit kontrolcü ve inverter sırasıyla panel, türbin ve çıkış gücü kontrolü için kullanılmıștır. Hava istasyonu rüzgar hızı, sıcaklık, ıșınım gibi hava verilerini kaydetmek için ve veri kaydedici de elektriksel büyüklükleri kayıt altına almak için kullanılmıștır. Sistem kullanılan bileșenlerin katalog bilgilerine göre modellenmiştir ve modelleme sonuçları ile uygulama sonuçları karşılaştırılmıștır.

Anahtar kelimeler: Hibrit sistem, Yenilenebilir enerji, Rüzgar enerjisi

produced electrical energy from wind energy in 2011 is 434 TWh [3]. The installed PV energy plant power has reached to $138,856 \mathrm{MW}$. Europe is the world's leading region with $81.5 \mathrm{GW}$ that is around $59 \%$ of the total installed PV system power, in 2013. In addition, the produced total energy from PV systems is 160 TWh in 2013 [4].

In the literature, there are many studies on analyze and design of renewable energy systems such as PV, wind and hybrid systems. In [5], a building integrated photovoltaic system is installed. Energy production is estimated and validated the using autoregressive integrated moving average model, artificial neural network and experimental results. Another study gives an information about grid connected photovoltaic power system that can be monitored on a website. Power, voltage and current harmonics of output are given in the study [6]. A shunt measuring technique is used to determine the electrical characteristic of multicrystalline silicon photovoltaic module in a desert area [7]. The performance analysis of a hybrid system that consists of photovoltaic panels, a wind turbine and a diesel generator as an auxiliary supply is presented. The system is analyzed depending on the load demand, meteorological conditions and characteristics of system components in [8]. In [9], a PV plant is installed to supply a rural village and to measure the system performance. It is observed that the system performance decreases when the load demand is low and the batteries have high state of charge. A stand-alone PV system with energy management is sized in [10]. Energetic cost and number of storage elements are 
reduced by energy management. In [11], a modelled hybrid photovoltaic/wind/fuel cells system that has different parameters of each subsystem is identified. The simulation and experimental results are compared to show the effectiveness of the proposed hybrid system. A linear programing optimization technique for a stand-alone system design considering minimize system cost and cost of energy is used in [12]. Capture loss and system loss hours in a day of system are obtained in the study. In [13], three different power management strategies and sizing approaches in hybrid PV/FC/battery stand-alone system are compared. Performance of the system is analyzed by TRNSYS software. Comparison of four sizing methods in hybrid stand-alone system that consists of PV/WT/FC is done in [14]. Two of four methods are based on mathematical model, and others were realized in optimization software HOMER and HOGA. In [15], a stand-alone PV system was designed and simulated by using MATLAB/Simulink. A new approach for PV module modeling was presented in [16] and also performance of experimental study was compared with suggested method. In [17] an aeroelastic model of small wind turbine was verified with experimental measurements.

The design studies on a PV system, a wind turbine system or a hybrid system are realized with model depending on datasheet of sources. The weather conditions such as radiation, temperature and wind are used in a model that is derived depending on the datasheet, and performance are investigated. However, real time performance does not give the same results with model. Modelling and experimental performance of a hybrid system are compared and presented to show the differences between the modelling and real time results.

In this study, simulation and experimental performance differences of the hybrid system that is installed in Yildiz Technical University is presented. The system has $600 \mathrm{~W}$ wind turbine, $2 \times 320 \mathrm{Wp}$ photovoltaic (PV) panel group and four $210 \mathrm{Ah}$ batteries. A maximum power point tracking (MPPT) controller, a hybrid controller and an inverter are utilized to control the panels, wind turbines and power flow. The system is modelled depending on the datasheets of the components, and the modelling results are compared with experimental results.

\section{Description of the hybrid system}

The hybrid system is built on the roof of Electrical Engineering Department building in Yildiz Technical University, Istanbul, Turkey. The system is located on the North-West of Turkey as seen in Figure 1. Istanbul is the most crowded and commercial city in Turkey. Therefore, electrical energy demand is quite high. Hence, use of distributed renewable energy systems is important in the city.

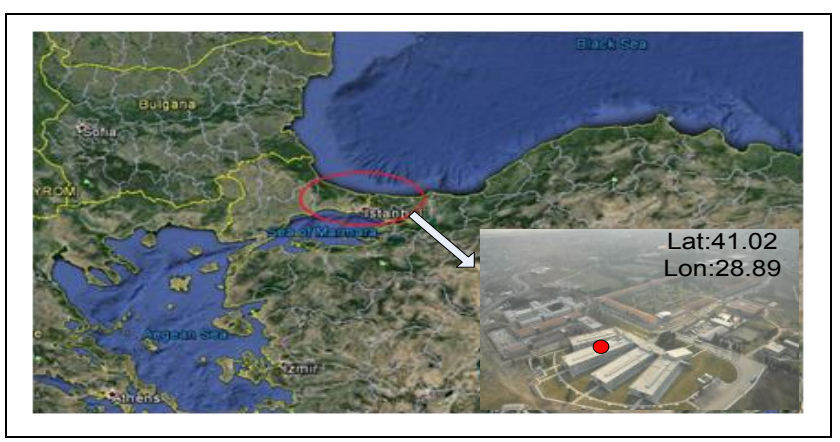

Figure 1: Location of the installed system.
Average wind speed and the annual solar radiation maps are given in Figure 2 and Figure 3, respectively. Wind potential of the region is in middle range. Average wind speed map shows that wind speed varies in 6-7 m/s. Radiation value of the region is around $1400 \mathrm{kWh} /$ year as seen in Figure 3. As the region is on the North of Turkey, it has low photovoltaic energy potential.

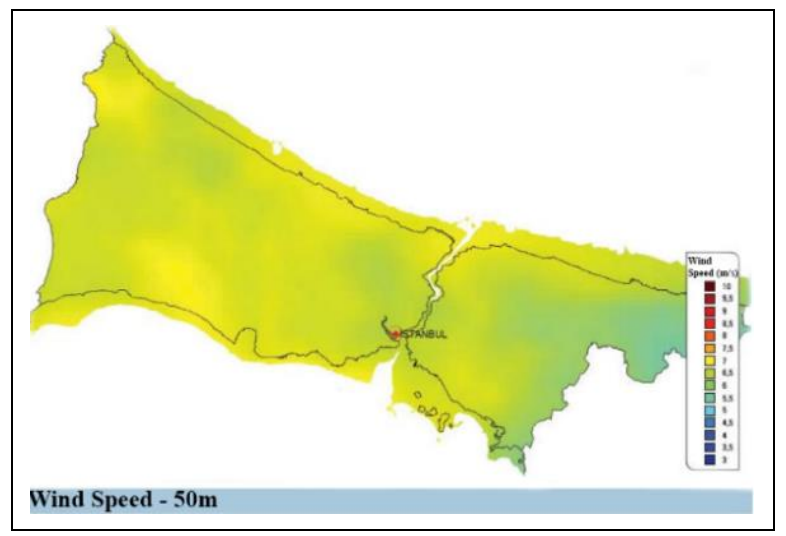

Figure 2: Wind speed of the region [18].

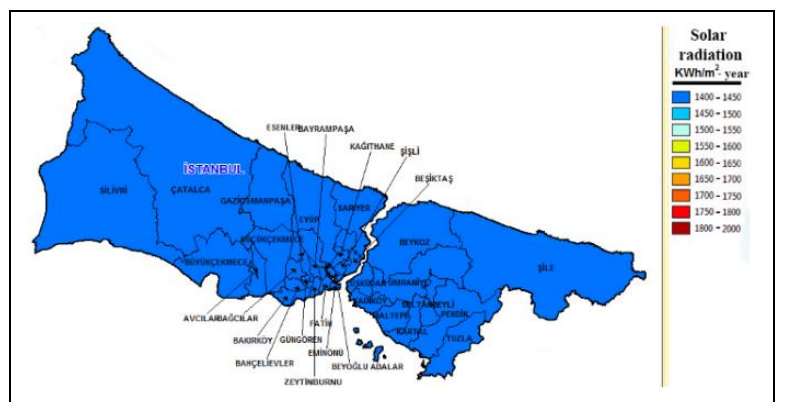

Figure 3: Solar radiation of the region [19].

The configuration of the hybrid system is seen in Figure 4. A 600 $\mathrm{W}$ wind turbine and a $320 \mathrm{~W}$ photovoltaic panel group $\left(\mathrm{PV}_{1}\right)$ are connected to DC bus via hybrid controller, whereas other 320 W panel group $\left(\mathrm{PV}_{2}\right)$ is connected via maximum power point tracking (MPPT) controller. A battery bank that has four 210 $\mathrm{Ah}-12 \mathrm{~V}$ batteries utilized as an energy storage, and a $1 \mathrm{~kW}$ inverter supplies the load. Solar radiation, temperature and wind speed are recorded by weather station for analyzing the system performance. Electrical quantities which are measured in the system are shown in Figure 4 . They are recorded by a data logger simultaneously.

The system has eight Mono-crystalline silicone PV modules (SL80CE-18M) in two groups. Each group includes four modules, and each module has $80 \mathrm{~W}$ power. Two of them are connected in serial, and serial connected panels are connected in parallel to increase the output current. The connection configuration provides $35.28 \mathrm{~V}$ output voltage, $9.08 \mathrm{~A}$ output current, and $320 \mathrm{~W}$ maximum output power could be extracted from the modules. Technical parameters of PV panel are given in Table 1.

Table 1: Technical parameters of PV module.

\begin{tabular}{cc}
\hline Parameter & Value \\
\hline Peak Power & $80 \mathrm{~W}$ \\
Maximum Power Current & $4.54 \mathrm{~A}$ \\
Maximum Power Voltage & $17.64 \mathrm{~V}$ \\
Short-Circuit Current & $4.85 \mathrm{~A}$ \\
Open-circuit Voltage & $21.92 \mathrm{~V}$ \\
\hline
\end{tabular}




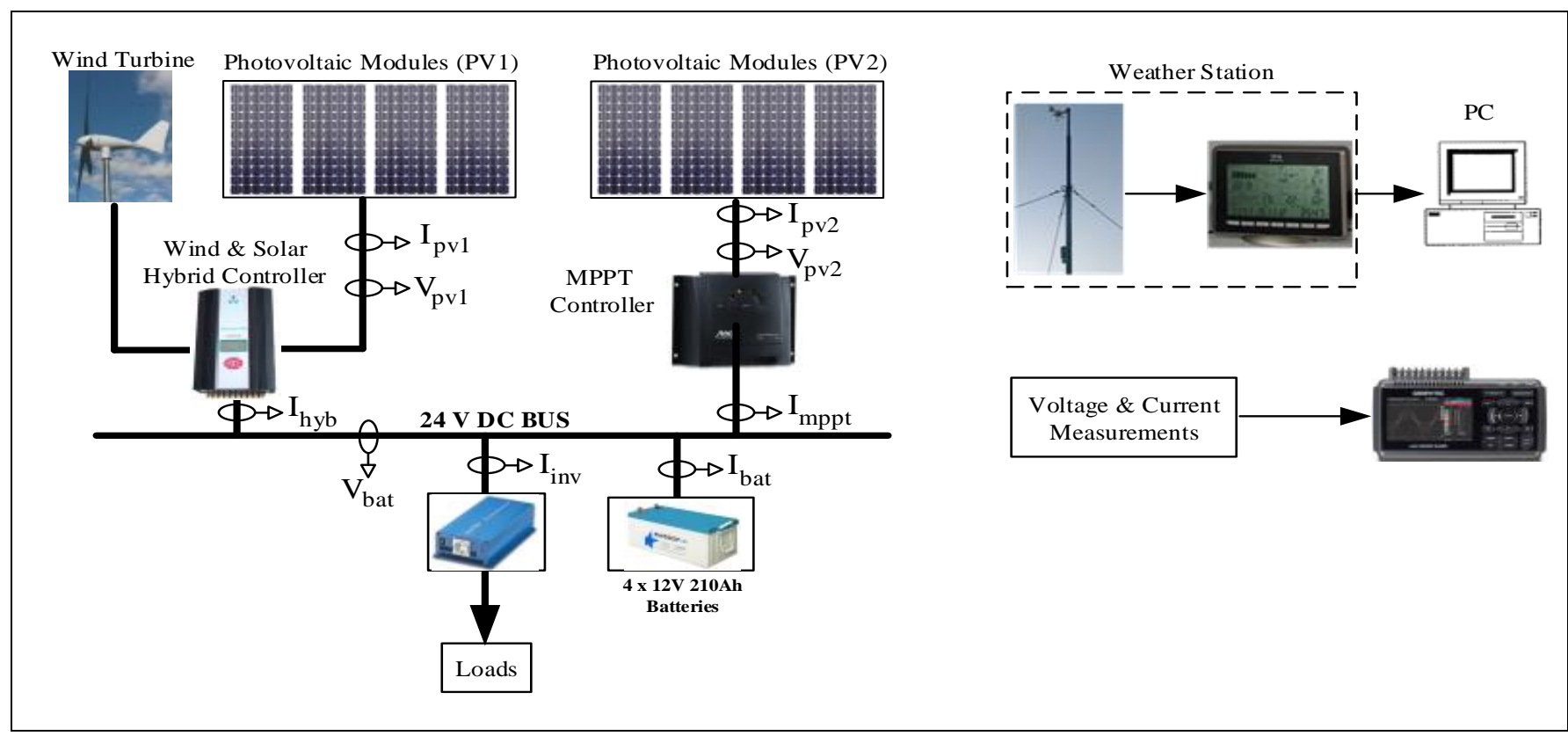

Figure 4: Connection and measurement block diagram of the hybrid system.

Three-phase wind turbine (Sunnily X-600W) is used in the system. The turbine has $600 \mathrm{~W}$ rated output power. The specifications and output power variation depending on the wind speed are given in Table 2 and Figure 5, respectively. The turbine is controlled by a hybrid controller, and has a protection against with $15 \mathrm{~m} / \mathrm{s}$ high wind speed.

Table 2: Characteristic values of wind turbine.

\begin{tabular}{cc}
\hline Quantity & Value \\
\hline Rated Power & $600 \mathrm{~W}$ \\
Max. Power & $700 \mathrm{~W}$ \\
Blade Number & 3 \\
Rotor Diameter & $1.85 \mathrm{~m}$ \\
Initial Wind Speed & $2 \mathrm{~m} / \mathrm{s}$ \\
Rated Wind Speed & $12.5 \mathrm{~m} / \mathrm{s}$ \\
Rated Speed & $600 \mathrm{rpm}$ \\
Generator Output & $3 \mathrm{Phase} \mathrm{AC}$ \\
Output AC Frequency & $0-300 \mathrm{~Hz}$ \\
\hline
\end{tabular}

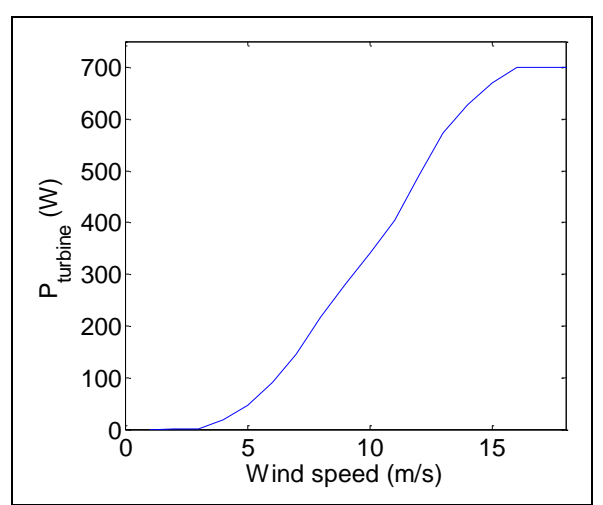

Figure 5: Output power curve of the wind turbine.

In academic and commercial wind turbine applications, output power curve of wind turbine is considered for sizing and total energy estimation. However, the instantaneous output power is controlled by a power converter. The performance of converter determines the wind turbine output power. The actual power curve could not be available in applications. The other power converters and storage elements in a wind energy system also could affect the total produced energy. The similar results are available in PV systems. MPPT controller performance and realtime efficiency of PV panels directly influences the energy production. As the mathematical model of PV panel is not the same with real electrical characteristics, efficiency of PV panel changes in different weather conditions. Therefore, experimental and simulation results show different results.

The picture of the control and measurement devices that are MPPT controller, hybrid controller, inverter, weather station, measurement board and data logger is given in Figure 6.
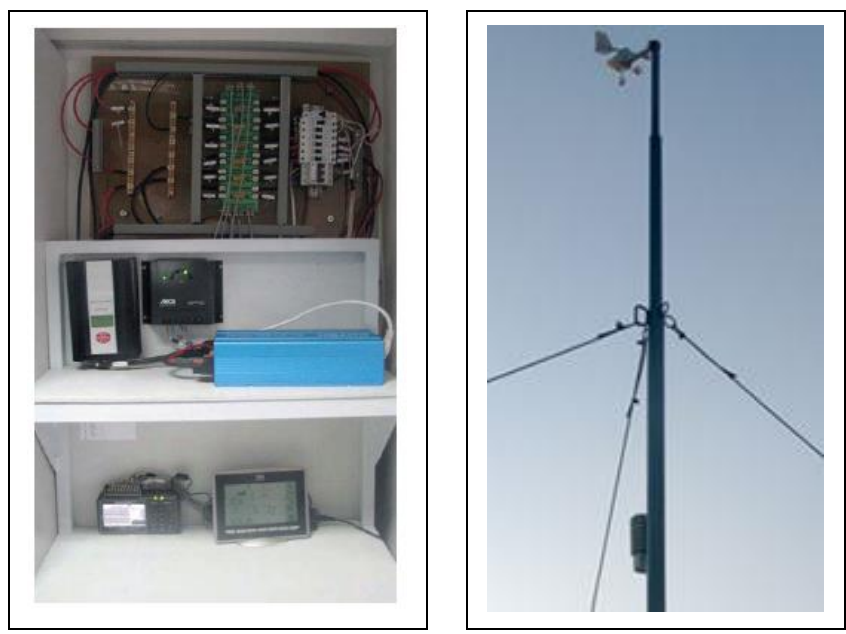

Figure 6: Conversion and measurement system.

$\mathrm{PV}_{1}$ panel group and wind turbine are controlled by a hybrid controller (WWS06A-24). It has operating modes that are named as voltage limiting and current limiting depending on the battery voltage. When the battery power is low, it operates 
in current limiting mode. Thus, it charges the battery with limited maximum current. It changes the operating mode to voltage limiting when battery power is high. The charge current is changed depending on the voltage level of battery. If the current that is extracted from wind turbine and PV panel is lower than the limited maximum current, whole current is injected to battery. When the total output power of sources is higher than the limited current, the battery is charged with limited current, and the excess energy is unloaded by PWM. Also, it operates in voltage limiting mode when battery voltage reaches over-charge value, and regulates the battery voltage in this mode. $\mathrm{PV}_{2}$ panel group is controlled by a MPPT controller (Steca MPPT 2010). This controller works to extract maximum power from panels while battery voltage is under over-charge value. When the voltage exceeds this value, it stops working until battery voltage decreases to restart value. Although two panel groups have the same electrical characteristic, output power values become different because of the differences of converter operating principle and limit values. Load of the system is fed by an inverter. It has deep-charge limit value to protect the battery and stops supplying the load when battery voltage is below $21 \mathrm{~V}$.

The power converters produced by different companies have different control algorithms. The differences of MPPT algorithms and level of DC bus voltage control directly affect the system performance. Converters stop the energy flow when battery deep charge and over voltage cases. Hence, energy cannot be produced from PV panels and wind turbines although convenient weather condition exists for energy production. Therefore, working principle and protection values of converters should be considered for system sizing.

In experimental study, electrical quantities, such as current and voltage, are measured by resistors that located on specific designed measurement circuit (shown in upper left side of the Figure 6) and recorded by the data logger (Graphtec GL220) that has 10 isolated channels. As the measured voltage values are in the measurement range of data logger, they can be measured directly. Measurement resistors are used to measure the currents. The currents are measured as voltage via resistors, and given to data logger. Thus, all electrical quantities are recorded to analyze the system. Measurement of weather conditions, such as wind speed, radiation and temperature, is done by a weather station (ES-2810) and pyranometer. The measured weather conditions are transmitted to recording device wirelessly. The recorded data are transferred to PC for signal analyze.

\section{Simulation of the system}

Renewable energy system and energy sources such as PV panel, wind, are modelled by any simulation software using catalog data in many studies. A developed model is simulated based on measured wind, radiation and temperature values. In this study, PV panel catalog data and wind turbine power curve are used in Matlab/Simulink as seen in Figure 7. PV module is modelled based on characteristic values given in Table 1 . Characteristic curves of the PV module are given in Figure 8 and Figure 9. The measured real-time radiation and temperature values are used in the model to calculate the output power. The power curve of the wind turbine that is given in Figure 5 is used to model of the wind turbine. The measured wind speed is given to the model for calculation of power.

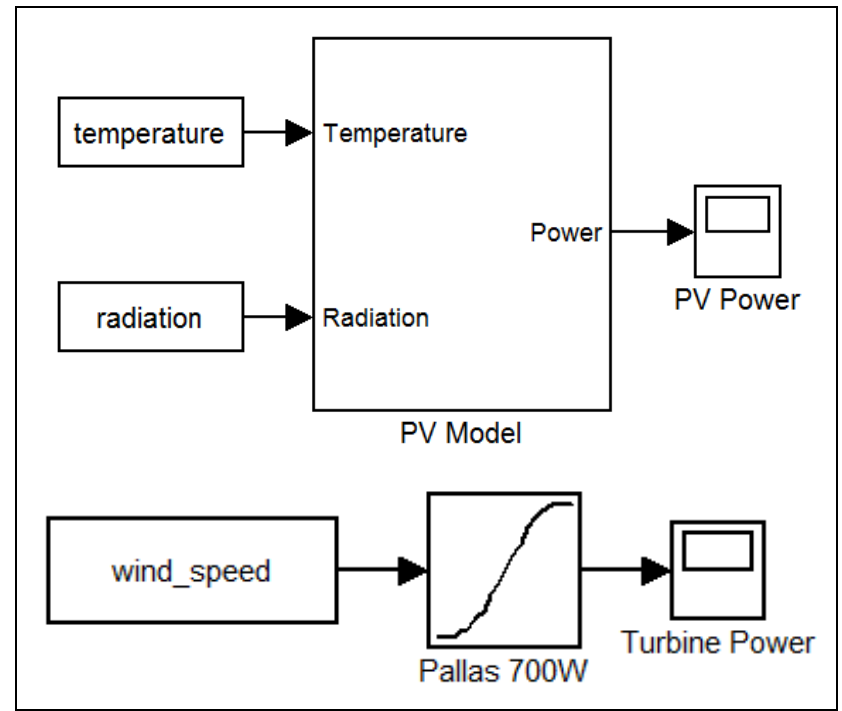

Figure 7: Simulink model.

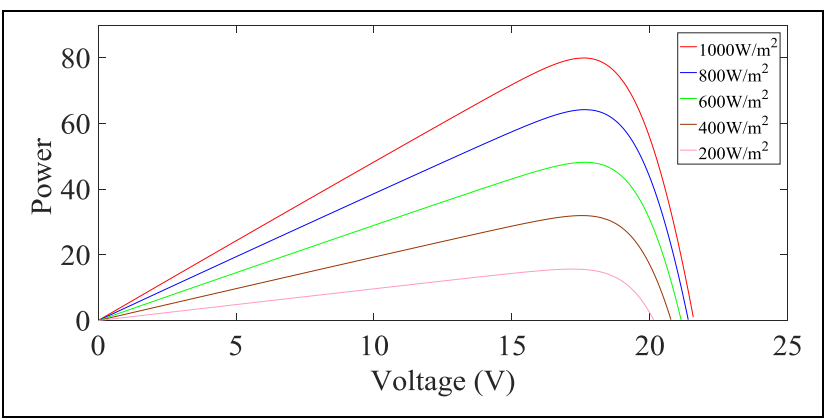

Figure 8: PV module $\mathrm{P}_{\mathrm{pv}}-\mathrm{V}_{\mathrm{pv}}$ curves.

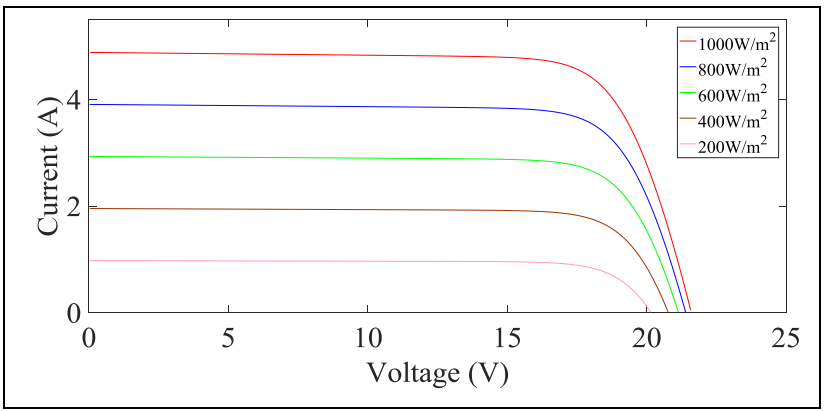

Figure 9: PV module $\mathrm{I}_{\mathrm{pv}}-\mathrm{V}_{\mathrm{pv}}$.

Output power of PV panel in model is given in Figure 10. As seen from the figure, power changes in the measurement time because of weather conditions. The average power is $95.72 \mathrm{~W}$ in measurement time interval.

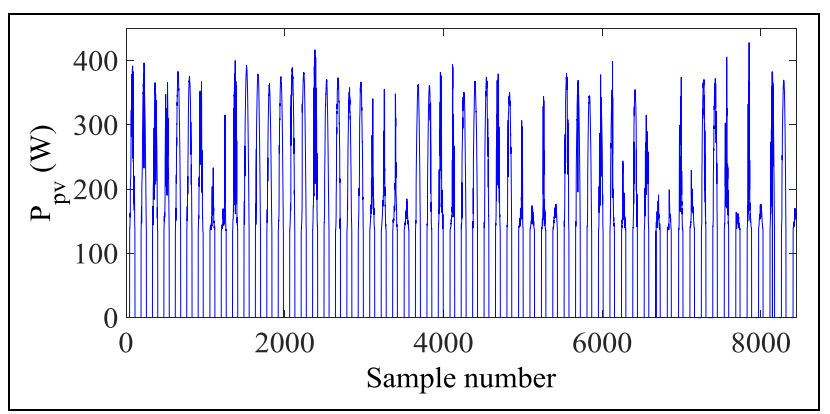

Figure 10: Output power of PV panel. 
Turbine output power variations are seen in Figure 11. The obtained power from model that is based on power curve in catalog varies depending on wind speed characteristic as can be seen in the figure. The produced average power by wind turbine is calculated $48.62 \mathrm{~W}$ in simulation. The weather conditions variations that affect the output power of wind turbine and PV panels are given in the next chapter.

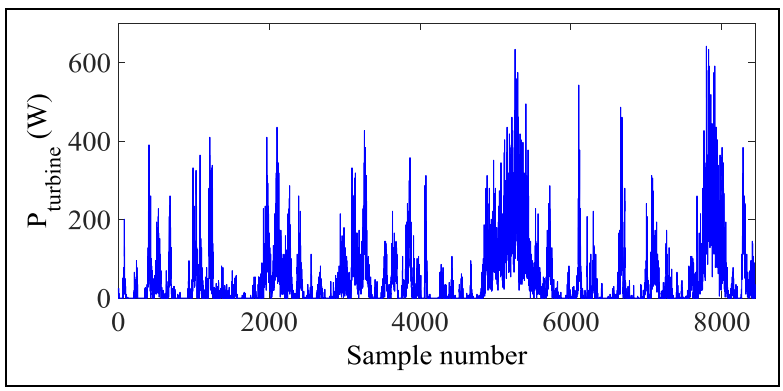

Figure 11: Turbine output power.

\section{Experimental results}

The experimental measurement results of the hybrid system that includes $640 \mathrm{~W}$ PV panel group, $600 \mathrm{~W}$ wind turbine, a MPPT controller, a hybrid controller, $1 \mathrm{~kW}$ inverter, $210 \mathrm{Ah}$ battery group, weather station and data logger are given in this chapter. In the study, the data that are recorded for 58 day between 10.10.2013 and 07.12.2013 is used in model. Temperature and radiation variations are shown in Figure 12 and Figure 13, respectively.

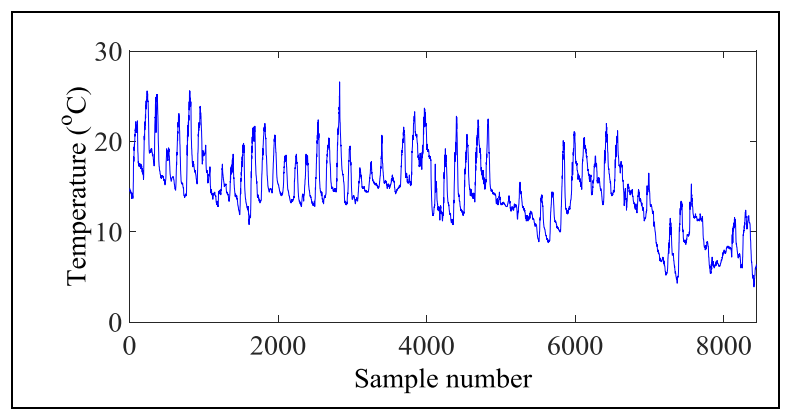

Figure 12: Temperature variation.

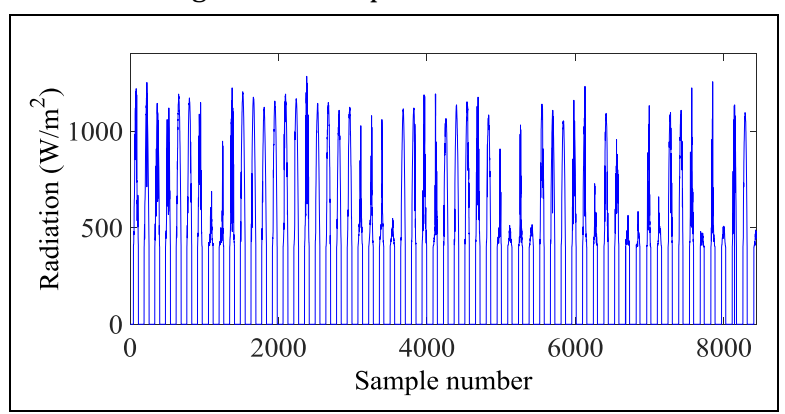

Figure 13: Radiation variation.

The total output power of PV panel group controlled by a hybrid controller is given in Figure 14 while the other PV panel group output power controlled by MPPT controller is illustrated in Figure 15. Although, the same PV panels are used in both groups, instantaneous output powers of panels are different each other because of using different controllers. The difference between two panel groups can be seen from Figure 14 and Figure 15. While the average power produced by $\mathrm{PV}_{1}$ is $52.32 \mathrm{~W}, \mathrm{PV}_{2}$ group produces $50.98 \mathrm{~W}$ power. The power difference in application decreases the accuracy of estimation that is done before system installation depending on the catalog data.

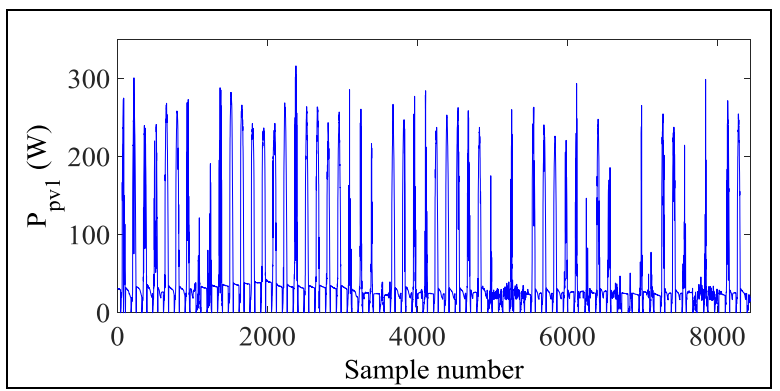

Figure 14: $P V_{1}$ output power.

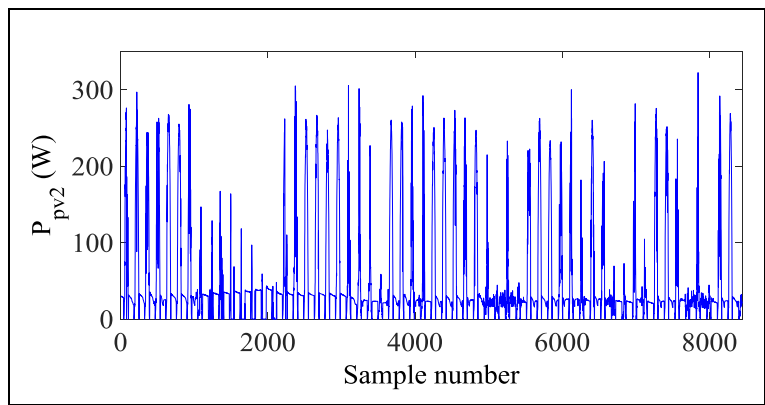

Figure 15: $\mathrm{PV}_{2}$ output power.

Figure 16 and Figure 17 show the wind speed and output power of wind turbine. In the measurement time interval, the average wind speed and power are calculated as $3.04 \mathrm{~m} / \mathrm{s}$ and $52.17 \mathrm{~W}$, respectively.

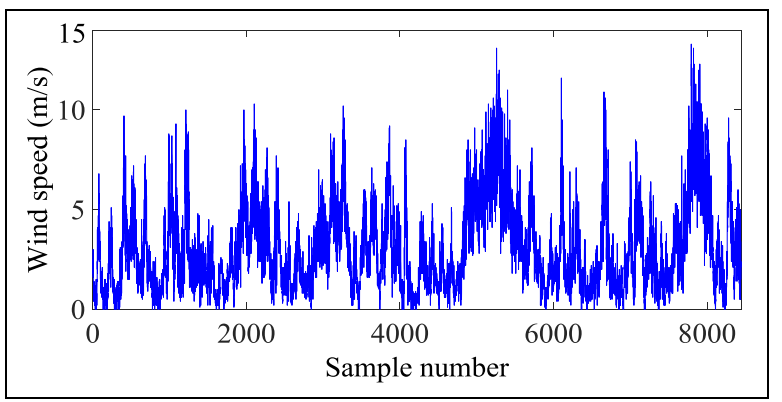

Figure 16: Wind speed.

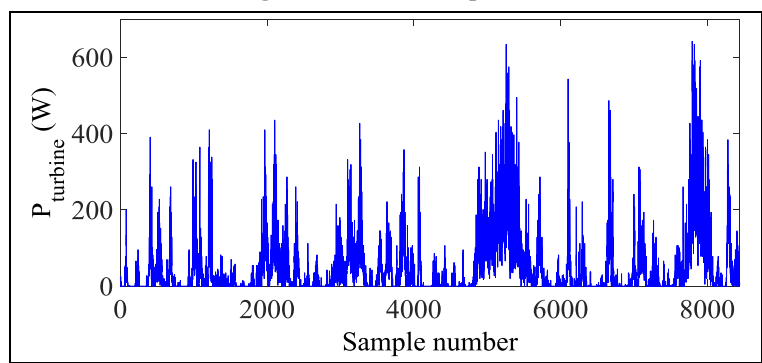

Figure 17: Turbine power.

\section{Discussion}

The results show that installation depending on the datasheet data has inadequate power capacity to supply load. It is an important consideration on stand-alone systems. Furthermore, power electronics converters should be in an integration. Each converter has different protection parameters for battery. Converters, such as maximum power point tracker and 
inverter, checks the battery voltage to protect the battery against deep-charge voltage and over-charge voltage. Depending on the default values, converters stop delivering the power to battery or load. If converters have inharmonious state of charge protection level, the system could needlessly stop, thus less power extraction is obtained.

Weather conditions, impurity, installation position, cabling, connection number and similar things effect the system performance and produced power. So, more considerations in system design provides higher experimental validity.

Table 3 shows the produced average power values by turbine and panels in experimental and modelling study. It is observed that experimental power is $35.24 \%$ lower than modelling power. As the modelling results are important for system design, component selection and load determination, the obtained power difference in experiment causes undesired operating cases.

Table 3: Comparison of produced average power.

\begin{tabular}{ccc}
\hline & Experimental & Modelling \\
\hline PV1 & $52.32 \mathrm{~W}$ & $95.72 \mathrm{~W}$ \\
PV2 & $50.98 \mathrm{~W}$ & $95.72 \mathrm{~W}$ \\
Turbine & $52.17 \mathrm{~W}$ & $48.62 \mathrm{~W}$ \\
Total & $155.47 \mathrm{~W}$ & $240.06 \mathrm{~W}$ \\
\hline
\end{tabular}

\section{Conclusion}

In stand-alone renewable energy systems, component selection is the most important criteria. The selection should be done depending on the maximum load demand, maximum power of energy sources, technical specification of converters and weather conditions in system installation region. The modelling and experimental results show that datasheet values of components do not give exactly true performance of the components. The simulation results that are based on modelling from datasheet data and curves show that the installed system supplies more energy to the load comparing with experimental results. As a result, it can be said that modelling results and experimental results are not fully compatible with each other for hybrid energy systems. It is because power electronics converters operating principles and unconsidered conditions. Therefore, it is required to consider application conditions and the specifications of all system components in system design.

\section{References}

[1] Park H, Kim YJ, Kim H. "PV cell model by single-diode electrical equivalent circuit". Journal of Electrical Engineering and Technology, 11(5), 1323-1331, 2016.

[2] Global Wind Energy Council. "Global wind statistics 2016". Brussels, Belgium, 2017.

[3] International Energy Agency. "Renewable energy outlookWorld energy outlook 2013". 197-232, 2013.

[4] European Photovoltaic Industry. "Global market outlook for photovoltaics". Brussels, Belgium, 2014.

[5] Fara L, Moraru AG, Sterian P, Bobei P, Diaconu A, Fara S. "Building Integrated Photovoltaic (BIPV) systems in Romania. Monitoring, modelling and experimental validation". Journal of Optoelectronics and Advanced Materials, 15(1), 125-130, 2013.
[6] Aktas A, Ozdemir E, Karakaya A, Ucar M. “Operation and performance of grid-connected solar photovoltaic power system in Kocaeli University". Journal of Optoelectronics and Advanced Materials, 15(5), 559-564, 2013.

[7] Ghitas A, Mageed HA, El-Rifate A, Schlosser V, Sabry M. "Validation of a new measuring system for performance evaluation of a large module in a desert area". Journal of Optoelectronics and Advanced Materials, 15(5), 565-570, 2013.

[8] Cubukcu M, Colak M. "Modeling, comparative simulation and practical performance analysis of a stand-alone PV hybrid power system in Turkey". Journal of Optoelectronics and Advanced Materials, 15(3), 352-360, 2013.

[9] El Fathi A, Nkhaili L, Bennouna A, Outzourhit A. "Performance parameters of a standalone PV plant". Energy Conversion and Management, 86, 490-495, 2014.

[10] Semaoui S, Arab AH, Bacha S, Azoui B. "Optimal sizing of a stand-alone photovoltaic system with energy management in isolated areas". Energy Procedia, 36, 358-368, 2013.

[11] Mezzai N, Rekioua D, Rekioua T, Mohammedi A, Idjdarane K, Bacha S. "Modeling of hybrid photovoltaic/ wind/fuel cells power system". International Journal of Hydrogen Energy, 39(27), 15158-15168, 2014.

[12] Sukchai S, Sirisamphanwong C. "Optimization of standalone PV-FC hybrid system under Thailand climate". Energy Procedia, 56, 309-317, 2014.

[13] Behzadi MS, Niasati M. "Comparative performance analysis of a hybrid PV/FC/battery stand-alone system using different power management strategies and sizing approaches". International Journal of Hydrogen Energy, 40(1), 538-548, 2015.

[14] Cano A, Jurado F, Sanchez H, Fernandez LM, Castaneda M. "Optimal sizing of stand-alone hybrid systems based on PV/WT/FC by using several methodologies". Journal of Energy Institute, 87, 330-340, 2014.

[15] Laurentiu F, Dan C. "Output analysis of stand-alone pv systems: Modeling, simulation and control". Energy Procedia, 112, 595-605, 2017.

[16] Drouichea I, Harrounia S, Arab AH. "A new approach for modelling the aging PV module upon experimental $\mathrm{I}-\mathrm{V}$ curves by combining translation method and fiveparameters model". Electric Power Systems Research, 163(A), 231-241, 2018.

[17] Evans SP, Bradney DR, Clausen PD. "Development and experimental verification of a $5 \mathrm{~kW}$ small wind turbine aeroelastic model". Journal of Wind Engineering and Industrial Aerodynamics, 181, 104-111, 2018.

[18] Yenilenebilir Enerji Genel Müdürlüğü. "İstanbul İli Rüzgar Kaynak Bilgileri". http://www.yegm.gov.tr/YEKrepa/ISTANBUL-REPA.pdf (18.09.2018).

[19] Yenilenebilir Enerji Genel Müdürlüğü. “Güneș enerjisi Potansiyel Atlası". http://www.yegm.gov.tr/MyCalculator /pages/34.aspx (18.09.2018). 